\title{
Seekers of Blessings (An Ethnographic Study of the Life of Beggars and Pilgrims in the Burial Area of Syekh Muhammad Arsyad Albanjari in Kalampaian Tengah Village, Astambul District, Banjar Regency, South Kalimantan)
}

\author{
Yuli Apriati $^{1 *}$ Alfisyah $^{1}$ Sigit Ruswinarsih ${ }^{1}$

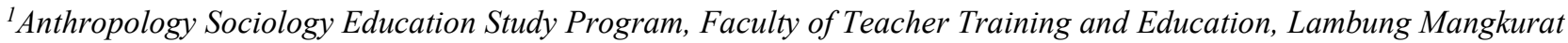 \\ University, Indonesia \\ *Corresponding author.E-mail:yuli.apriati@ulm.ac.id
}

\begin{abstract}
Among social problems that still exist in Indonesia, beggars became prominent social problems that difficult to be solved. The panhandling activities have been seen not only in the streets but also in several cemeteries. The beggars asked money from people who pilgrim in the cemetery of prominent moslem spiritual leaders. Syekh Muhammad Arsyad Albanjari was prominent Moslem leader that live in Martapura in the era of Banjarese Sultan. He were died in Inside the Fence, October 3, 1812 and buried at Kalampayan. His cemetery were popular to be pilgrim by people especially Banjarese. There are so many Beggars in that cemetery and asked money from pilgrim. They were happy to be called by the panhandler rather than beggars. Beggars in this cemetery area consist of various age background from Old, Adult, and Child, between 3 to 70 years old. The duration of panhandling is between 2 to 20 hours of work. They were working from 09.00 in the morning to 17.00 at the afternoon. The income of Old and Adult beggars are higher than child beggars. The factors that caused panhandling activities are; poverty, alienation base on lack ability of education, work, and technology. The population of Beggars will be increase when the moslem celebrate their holly days. The usualy go to pilgrim in that cemetery.
\end{abstract}

Keywords: local culture, characteristic, panhandling

\section{INTRODUCTION}

Indonesia is one of the countries that is still at the stage of development or is called a developing country and is still facing various social problems that sometimes can hinder national development. Various attempts have been made by the government to overcome social problems that occur in order to create better development and ensure the welfare of its people. However, until now the people's welfare is still a big problem that needs handling.

The 1945 Constitution Article 34 Paragraph 1 states that the poor and neglected children are cared for by the state. The 1945 Constitution Article 34 Paragraph 1 means that beggars, homeless people and street children are cared for or empowered by the state, in this case the government. The poor here can be described through vagrants and beggars. However, in reality the presence of beggars is still widely seen, especially in urban areas such as on the streets, crowded centers, red lights, houses of worship and schools.

The cause of this problem is apart from the number of population growth that is not matched by adequate employment opportunities and job opportunities that are not always the same. The narrowing of agricultural land in the village is because it is widely used for residential development and companies or factories. No less important, due to cultural and social system problems that gave birth to the tradition of begging, as was the result of Rina's study of beggar behavior in Praga Village, Sumenep, which was nicknamed the Beggar Village [1].

According to Koentjaraningrat, urban poverty is caused by those who do not get a good job, they occupy jobs that are not promising and they will automatically fall into the preprosperous group and create a new problem, namely urban poverty [2].

In addition, it is exacerbated by a 'culture of poverty', according to Oscar Lewis, which is much more difficult to eradicate a culture of poverty than poverty itself. The behavior and culture of the poor also affects their poverty. Therefore, once poverty strikes, the norms, behavior and culture of poverty that develops in that life tends to perpetuate the state of poverty [2].

The existence of beggars in South Kalimantan is difficult to overcome. They can be found at various road junctions, intersections, traffic lights and public places, in residential 
areas and even in the burial area of certain figures, beggars can also be found. Most of them make begging as a profession. The general problem of beggars is in essence closely related to the issue of order and security which disturbs public order and security in urban areas. With the development of beggars, it is thought that it will provide opportunities for security and order disturbances, which in turn disrupt stability so that development will be disrupted, which in turn will hinder national ideals.

The existence of beggars in South Kalimantan is based on data released by the Ministry of Social Affairs in 2013, the number of people with social welfare problems in South Kalimantan is 311.251. Of these, 743 of them are beggars as shown in the following table.

Table 1. PMKS (Persons with Social Welfare Problems) Data for South Kalimantan Province 2013

\begin{tabular}{|l|l|l|}
\hline No & Nama Social Problem & Number of People with Problems / Lives \\
\hline 1. & AAbandoned toddler kid & 2654 \\
2. & AAbandoned son & 9421 \\
3. & ANaughty kid & 537 \\
4. & Akid Street & 187 \\
5. & Wanita is prone to socio-economics & 14,532 \\
6. & Korban of Abused Elderly Persons with Disabilities & 382 \\
7. & Tuna Susila & 18,815 \\
8. & Beggar & 19,621 \\
9. & Gelawelcome & 943 \\
10 & Poor People & 743 \\
11. & ExPoor poor family & 141 \\
\hline
\end{tabular}

Source: Ministry of Social Affairs data, 2013

One of the places in the South Kalimantan region where beggars roam around is the tomb of Syekh Muhammad Arsyad Al-Banjari or better known as Datu Kelampaian. Syekh Muhammad Arsyad Al-Banjari is a great scholar of Islam in South Kalimantan who is considered to have had a great service in the process of spreading Islam in this region. Therefore, like the graves of other great figures, the Datu Kalampaian funeral complex is visited by many pilgrims to make pilgrimages.

Every day, the Datu Kelampaian tomb is visited by pilgrims from various regions, both domestic and abroad. The location of Datu Kelampaian's grave is located in an area in Astambul District called Kelampaian Tengah Village, so people also know its nickname as Datu Kelampaian, it is located approximately $15 \mathrm{~km}$ from the center of Martapura City, Banjar Regency.

The number of pilgrims who visit every day to the grave of Datu Kalampaian makes this area a land for beggars to ask for alms from pilgrims. There are many beggars who chase the pilgrims, stretching out their hands as a sign that they hope to be given alms by pilgrims. Approaching the location of the grave, about $6 \mathrm{KM}$ away to the destination, pilgrims were treated to beggars seeking attention and compassion from pilgrims passing to the tomb of Datu Kelampaian. Along the side of the road, young and old, men and women sitting on the side of the road stretched out their hands or hats with the intention of asking for donations or charity from passing pilgrims. There were approximately 20 beggars who were met by the side of the road along the $6 \mathrm{~km}$ before entering the Datu Kelampaian burial complex. Entering the Datu Kelampaian grave complex, the atmosphere has begun to be different, the beggars are being met and the more aggressive they are towards pilgrims visiting the Datu Kelampaian grave.
There are approximately 25 beggars roaming around the Datu Kelampaian tomb complex.

The government has actually tried to make a policy by making the Regional Regulation of 2010 article 4, which prohibits the activities of vagabonds and / or beggars. In fact, the presence of beggars around the grave of Datu Kelampaian who take advantage of this condition to ask for mercy from people who visit is still ongoing.

This paper will try to examine in depth about beggars in South Kalimantan, especially beggars in the funeral complex of Syekh Muhammad Arsyad Albanjary in Kalampaian Village with a focus on studying the life of beggars and the factors that cause the existence of beggars, using an ethnographic approach. Ethnographs have unique characteristics such as full involvement of researchers, exploring community culture, and require depth of data exposure[3]. Begging in the grave area of Datu Kelampaian is not only caused by poverty problems, but also related to cultural issues and local social systems, so it is necessary to study in depth through this ethnographic approach.

\section{METHOD}

This study uses a literature review or literature review. Literature review is a method used to collect data or sources related to a particular topic that can be obtained from various sources such as journals, books, the internet, and other literature. 


\section{RESULTS AND DISCUSSION}

\subsection{The Life of Beggars in the Burial Area of Sheikh Muhammad Arsyad Albanjari (datu negligence)}

One of the social problems that is still a big phenomenon is happening in Kelampaian Tengah Village, Astambul District. He found many beggars roaming around the grave of Datu Kelampain and along the road to the tomb. Their lives are reflected in their personal characteristics. According to KBBI, character means psychological, moral or character traits that distinguish a person from another, or means innate, heart, soul, personality, character, behavior, personality, nature, character, temperament and character [4]. According to Stephen Robbins, there are four individual characteristics, namely biographical characteristics, ability characteristics, personality characteristics and learning characteristics. Biographical characteristics include several characteristics, namely age, sex, and race [5]. Some of the characteristics that exist in beggars around the Datu Kelampaian grave complex. Each beggar has different characteristics such as gender, age, hours of operation, location of begging, area of origin and daily income of each beggar.

The ages of the beggars around the Datu Kelampaian tomb generally range from 3 to 70 years. The largest group is beggars who are around 25-35 years old, because at that age many beggars have families and have children, making them have to have income to make ends meet. Due to low education, no beggar has completed his primary school education, making begging the main source of income. In addition, there were also beggars with physical weaknesses who began to bend over, wrinkled faces, aged around 50-70 years old who were begging around the grave of Datu Kelampaian. No less a lot of child beggars were also found around the grave of Datu Kelampaian, the children ranged in age from 3-12 years. Seen from gender, beggars are not only male but also female. Female beggars were found to be more than male beggars, this was seen when female beggars were around Datu Kelampaian's grave.

The majority of beggars here use purun hats and stretch out their hands as a means of entering the money given by pilgrims. Suparlan emphasized, beggars often ask by using glasses, small boxes, hats or other objects that can be put in money [6].

The beggars around Datu Kelampaian's grave also have variations in their tenure or length of time as a beggar. Some have for decades made a living by being a beggar, which is about 20 years. There are also those who have only been begging for 2-3 years around the grave of Datu Kelampaian. The length of time being a beggar does not affect the amount of daily income, nor does it make pilgrims who want to give alms to differentiate the beggars around the grave of Datu Kelampaian.

In general, the beggars around the Datu Kelampaian grave are native residents of Astambul District, and the natives of Kelampaian Village itself both from Kalampaian Ulu and Kalampaian Tengah villages, but there are also beggars who come from Limamar and Galam Rabah villages. The house of the beggars is not far from the location of the begging location, it only takes five to seven minutes from the house to the location of the begging place by foot. The farthest is from Limamar, about 10 minutes by bicycle. With the different residence distances, there is no difference in the operating hours of the beggars around the Datu Kelampaian grave.

The operating hours of beggars are generally the same except on certain days. If on normal days beggars start their activities at 09.00 or 10.00 am go to the location where they are begging and come home early around 16.00 in the afternoon then on holidays and Islamic holidays such as Eid al-Fitr or Eid al Adha, or weekends such as Saturday and the week of the beggars came earlier than the usual hours, namely around 08.00 am and came home later around 17.00 and even until 18.00. According to Dimas, in general, the living quarters of beggars are not far from the location of begging, this is due to environmental conditions that cannot seek employment opportunities, making them work as beggars [7].

Viewed from the educational aspect, the beggars around the Datu Kelampaian grave generally do not have a high educational background, their highest education is only elementary school, and some of them have never received any formal education at all. With low education, it is difficult for them to get decent jobs. This low education of beggars forces beggars with limited abilities to become beggars as the only work that can be done.

The location used as a place to beg can be classified into two, namely on the kertak (road) and the location of the burial complex. The location of this begging is quite affecting the income of beggars. Beggars who get a lot of alms from pilgrims are around the entrance hall and around the grave of Datu Kelampaian. This is because at the location of this grave the pilgrims are more concentrated and the interaction between beggars and pilgrims is also more intensive. There are also demarcation and zoning of begging areas. Along the entrance hall to the grave, beggars are more attractive to beggars, both children, the elderly, and adults.

Adult beggars and old beggars earn more than child beggars. This can be seen from pilgrims who more often give alms to adult beggars and old beggars with a larger nominal amount such as two thousand, five thousand rupiah. Meanwhile the children are usually one thousand, or five hundred rupiah. This is with the intention of not getting used to small children who should be studying seriously instead becoming beggars around the grave of Datu Kelampaian. Since childhood, the children have been accustomed and taught not to want to try better than a beggar, making them lazy and only expecting gifts from passing pilgrims.

\subsection{Local Cultural Linkages as a Cause of Asking}

Many people think that social problems occur because there are things that are wrong or not right in people's lives. Eitzen distinguishes between two approaches in diagnosing problems, namely the person blame approach 
and the blame approach system. The person blame approach as the name implies in making a diagnosis places the individual more as the unit of analysis. The source of social problems is seen in the factors inherent in individuals with problems, with the assumption that the source of social problems lies with the person with the problem. The causative factors may come from physical, psychological, and socialization processes. On the other hand, the system blame approach which focuses more on the system as a unit of analysis to find and explain the source of the problem, will find the factors that cause problems from aspects related to the system [8].

The factors that cause the choice to become a beggar can be seen through these two factors. Where the things that become the reasons for someone to beg can be known to the individual who carries out the begging activity itself and can also be seen in the influence of local culture. Among the culture, the Banjar people are fond of pilgrimages to the graves of the religious scholars. So that the graves of the religious scholars are always visited by pilgrims every day, including the tomb of Datu Kelampaian. Alms given by pilgrims to beggars are one of the reasons for being granted the wish during the grave pilgrimage. So that this triggered a large number of beggars around the graves, especially around the graves. As Oscar Lewis explained, it is much more difficult to eradicate a 'culture of poverty' than poverty itself. From this background, it can be seen the problems faced by beggars around the grave of Datu Kelampaian. Susanto explained that there is no one 'panacea' that can fight poverty comprehensively, let alone completely [9]. The poor are certainly not a homogeneous group of people. The poor may not be able to have access to vital facilities and infrastructure because they live in resource-poor areas or because they are vulnerable to life expectancy, health, housing or employment. The beggars around Datu Kelampaian's grave will have far access to the city because they live in rural areas with an environment that is more dominated by agricultural land and few jobs. Physical limitations make people think of looking for work that begs. Their family background is far from sufficient to make them think about pursuing any kind of work in order to get financial resources.

According to Koentjaraningrat, there are differences between the two major groups in society that show a different mentality, namely rural and urban people [2]. Village people usually work in the agricultural sector, and their mentality is a special mentality, which is called the farmer mentality. On the other hand, urban people work as laborers, traders, entrepreneurs or employees. Kelampaian Village is a village with large agricultural land. So that the majority of the population works as farmers, namely 195 people from the total population of 1,444 people. Being a beggar around the grave of Datu Kelampaian is an example of the mentality of the villagers who work to take advantage of the conditions around them.

This fact can be seen in the nature of the beggars around the grave of Datu Kelampaian. For them, there is no more work that can be done apart from being a beggar. They doubt the potential that humans always have to be able to do something better. Do not believe in one's own potential so do not want to try to find a better job than a beggar. In addition, a mental attitude that ignores responsibilities is also seen from the head of the family. This makes female beggars have to share the burden of earning a living for their children. The head of the family who does not want to try to get a permanent job with an uncertain income results in family members having to intervene in making ends meet.

It turns out that the existence of children is one of the reasons for being able to provide for it by being a beggar around the grave of Datu Kelampaian. Beggar children are born in a social environment that indirectly forms a lazy attitude, since childhood the children have been invited to become beggars when the child's development begins to grow. Since childhood, these children have found it difficult to earn money. This fact is in accordance with what was stated by J. Kosa and IK Zola that the condition of being poor as a social environment where children are raised does not support or help develop personal character or traits that can break their poverty [10].

The beggars around Datu Kelampaian's grave are not only beggars for the elderly but also for children. Where they should study seriously in order to achieve what they aspire to, instead they have to work in the world of begging for the intention of getting money as an addition to pocket money and as additional money for school needs. When school holidays and after school, the children beggars can be found around the grave of Datu Kelampaian, running around chasing beggars hoping that there is a small amount of money given to them.

Begging activities are used solely for daily food purposes. The proceeds they get everyday from begging buy directly rice, groceries for daily meals, even money from begging is also used to buy cigarettes and coffee. For purposes other than food, such as clothes, you can only buy them when you have sufficient savings. Sometimes beggars also get alms in the form of basic necessities and clothing.

In addition, the work of the head of the household is also a factor in ensuring the welfare of the family. The head of the family is required to be able to make a living for the family he leads, while the reality in the field is that there are many family heads who do not have permanent jobs. It was also found that many were unemployed, no one expected the power of the head of the household who should be the backbone of the family he built. Therefore, by being a beggar for women who are married beggars can help the family economy even though they have little income and can only eat their daily family meals.

A beggar with physical disabilities is clearly seen and it is known that he is begging to survive. With his paralyzed leg, no one cared about his family, so earning money by begging was an option to be able to buy the food he needed daily so he could live. Based on the results of the flat research in Tanah Bumbu Regency, various methods are used by beggars so that the givers feel sorry for them and give their contribution. Among them, wearing shabby clothes, showing a sickly body condition, to wearing 'pity talisman' [11]. In addition to maintaining his life, being a beggar is considered the easiest job. Only by sitting 
sweetly waiting for pilgrims to pass by, pilgrims will naturally feel sorry for them and then give their alms to them. The ease and convenience of earning money in this way have made beggars around Datu Kelampaian's grave not want to try another job because they are comfortable with what they are doing now.

Apart from physicality, age is an excuse for not wanting to work for another one. Often sick, with a weak body condition to do heavy work, only by being a beggar can you get money. Being a beggar around Datu Kelampaian's grave is just sitting around waiting for pilgrims to pass by who volunteer his alms to beggars without having to exert energy.

Another case with beggars for children, being a beggar around Datu Kelampaian's grave is a side activity between them playing. The location of begging turns out to be used as a place to play with friends which is also a place for them to beg. For child beggars, begging is an activity that can get money in addition to their snacks and additional money for school needs.

The income generated by beggars is not much in a day. However, there are certain days where the visitors are busy and give alms a lot. Like holidays, the day before or after the month of Ramadan, after Eid and Adha. For the beggars around the grave of Datu Kelampaian, the income on those busy days is indeed promising, some money can be saved for sudden future needs. However, it is different on normal days where only a few pilgrims come, in the morning around 08.00 am beggars have started to go to the location to beg until 17.00 in the afternoon. Within a day it could be sufficient for daily food. This is in accordance with the statement expressed by Rah Mukti that meeting the needs of their life (beggars), this begging job is considered quite promising in terms of material. With the working hours from morning to evening, the expected results are satisfactory for the beggars. This of course will trigger those who were not beggars to change jobs to become beggars[12].

According to Rohman, the factors that occur begging are:

a. The person concerned is completely powerless to do other work due to his physical disability, no education, no permanent housing.

b. Losing shame and moral burdens in front of society

c. Seeing the times when people give alms a lot, such as the month of Ramadan, before holidays and new years.

d. Begging because of mental poverty and laziness to work.

e. Beggars who are coordinated in a syndicate [13].

The beggars around the grave of Datu Kelampaian are included in the four reasons stated by Rohman. Meanwhile, point number five was not found in the beggars around the Datu Kelampaian grave. This is also in line with Umi's findings, there are several categories that make a person become a beggar, namely poverty, physical disability, old age, laziness and cultural factors [14].

Being a beggar is the only choice beggars should make. The inability to be able to live by looking for work other than begging because there are no opportunities and alternatives from a low educational background, as well as a family environment that is not supportive of getting a better life. There are also beggars who are seasonal beggars, only about two to three years of being a beggar, initially a farmer, although he used to often beg, but just before a busy day, pilgrims just like Eid al-Fitr, Eid aladha, or the commemoration of big holidays. Other Islam. When the day is busy farming.

Dimas said that there are several factors that cause people to beg, including the first being lazy to do business, second, physical disabilities (physical disabilities). Third, the high cost of education is also the reason for the many beggars. Fourth, the absence of employment opportunities is increasingly difficult to find. Fifth, told by parents. Sixth, he is helpless [7].

The beggars around the Datu Kelampaian grave, in fact some of them are still physically fit and able to do other jobs besides begging. Begging is considered the most pleasant and tiring job because just sitting after the pilgrims who pass by will get alms, not only money but clothes and food.

The physical disability factor (physical disability), which is better known as a physical disability, is also a reason for begging. Actually, in the case of beggars, not all of them are liars, there are also those who have limited physical abilities who prefer to beg rather than work. The reason is because no company would accept people with physical disabilities.

This happened to beggars who were around the grave of Datu Kelampaian. Being a beggar has been done for decades, every day spending time looking for money begging around the grave of Datu Kelampaian. With their physical disabilities, they have to become beggars. Do not have the physical strength to be able to work, so they can only make money as a beggar. The daily necessities of life and food of a beggar can be fulfilled with a modest income. The high cost of education causes not everyone to get the education they should. With the low educational background of beggars and the economic condition of the family which is far from those who are located, it makes them unable to continue their education to higher education. This low educational background makes them unable to have a higher and better job status and type of work, does not have a reliable background in skills and is unable to do a better job than a beggar.

Difficult jobs in accordance with abilities. This narrow job field forces the beggars around the grave of Datu Kelampaian who have limited abilities to make begging as the only job that can be done. In addition to the increasingly difficult job opportunities to find, they took advantage of the environmental conditions of the Datu Kelampaian tomb as a place to be used as a location for begging.

Parents ordered. Usually this reason is found in child beggars. They work because their parents encourage and let them work. This happened to the beggars around the tomb of Datu Kelampaian. These beggars for children who are just in elementary school can be found begging around the afternoon and during school holidays. Around the 
grave of Datu Kelampaian, the pilgrims were treated to many beggars for children, both boys and girls, to spend their time playing while begging in that place. Being beggars around eating Datu Kelampaian for the children is a side job while they become students. On the other hand, begging is an encouragement from parents who support them to find money for additional snacks and school fees. In general, they spent time around Datu Kelampaian's grave until late afternoon. They go home by themselves because tomorrow morning they have to return to school as students. The money from begging is used for daily pocket money, if their parents don't give pocket money then the money from begging is used.

The last factor or that is already powerless. For the elderly, asking is the only way. The old beggars didn't have enough strength to work like they did when they were young. Some of the beggars around the grave of Datu Kelampaian are elderly, namely around 50 to 70 years. This elderly beggar admitted that he was often sick and his energy weakened so he chose to be a beggar who just sat on the side of the road or in front of the entrance to Datu's grave. In addition, the residence is also a reason for beggars to be beggars around the grave of Datu Kelampaian. The house which is close to the location of begging makes them not have to walk far to the location where he begs.

With an aging age, the beggars around Datu Kelampaian's grave only live an old life by begging. The income that is generated is not much, but it can help the family to meet daily food needs such as rice and groceries.

\section{CONCLUSION}

The problem of begging around the Datu Kelampaian tomb was motivated by various causes. These causes include poverty and local culture. The local culture of the Banjar people participates in grave pilgrimages to the graves of the religious scholars and guardians, because pilgrimage is understood as a means of facilitating the fulfillment of the wish. An assumption is that the pilgrims' alms to beggars is one of the causes of granting the pilgrim's wish. This prompted an increase in beggars around the tomb. The demands of the necessities of life and the absence of assets cause them to do begging work to be able to make ends meet. The number of beggars around the Datu Kelampaian grave usually increases before or after the commemoration of Islamic holidays. Children are also the cause of female beggars to become beggars around the grave of Datu Kelampaian, the sustenance she gets daily through begging for most of the necessities of life for her children. Another cause is physical disability which is used as an excuse for not having the power to do other work, resulting in laziness in trying to do a job that is even better than begging. In addition, the low level of education of beggars has an impact on jobs that are hard to find. For the beggars of the children, begging around the grave of Datu Kelampaian is encouragement from their parents. Another cause is physical disability which is used as an excuse for not having the power to do other work, resulting in laziness in trying to do a job that is even better than begging. In addition, the low level of education of beggars has an impact on jobs that are hard to find. For the beggars of the children, begging around the grave of Datu Kelampaian is encouragement from their parents. Another cause is physical disability which is used as an excuse for not having the power to do other work, resulting in laziness in trying to do a job that is even better than begging. In addition, the low level of education of beggars has an impact on jobs that are hard to find. For the beggars of the children, begging around the grave of Datu Kelampaian is encouragement from their parents.

The beggars around the Datu Kelampaian tomb have certain characteristics. These characteristics include age which can be classified into three groups, namely children, adults and elderly or old. The most common ones were adult beggars around 25-35 years old, then older beggars aged 50-70. Meanwhile, the beggars for children aged 312 years did not appear to be as many beggars as adults. There are beggars around the grave of Datu Kelampaian who have for decades made a living by being beggars, namely around 25 years, 5-10 years and some are only 2-3 years. In general, the beggars around the Datu Kelampaian grave are natives of Kelampaian Village. Another characteristic is the place and hours of operation they beg for. The place to beg can be classified into two, namely kertak and around the grave complex. The operating hours of begging parents and adults are every day at 9:00 a.m. to 5:00 p.m., while begging for children is often encountered during school holidays at 10:00 to 18:00 in the afternoon and when leaving school at 14.00-18.00 in the afternoon. The income generated also varies between adult, old and child beggars. Adult beggars and old beggars outnumbered child beggars. The income generated also varies between adult, old and child beggars. Adult beggars and old beggars outnumbered child beggars. The income generated also varies between adult, old and child beggars. Adult beggars and old beggars outnumbered child beggars.

\section{REFERENCES}

[1] R. Hardiyantina and S. Sukardi, "The Ethnographic Study of Beggar Behavior in Praga Daya Village Community, Sumenep Regency," Publications J. Science Adm. Public, vol. 1, no. 1, 2016, doi: 10.26905 / pjiap.v1i1.428.

[2] Koentjaraningrat, Culture Mentality and Development. Jakarta: PT Gramedia, 2004.

[3] Windiani and F. Nurul, "Using ethnographic methods in social research," Dimens. J. Sociol., vol. 9, no. 2, pp. 87-92, 2016.

[4] \& RDA Suharso, D., Indonesia Dictionary. Semarang: Widya Karya, 2002.

[5] R. Stephen P, Organizational Behavior 8th Edition Volume 2. Jakarta: PT Perlindo, 2007.

[6] S. Suparlan, Homelessness A Consequence of Urban Development. Jakarta: LP3ES, 1993.

[7] Dimas, Undercover beggar. Jakarta: Titik Media, 2013.

[8] Soetomo, Social Problems and Solutions Efforts. 
Yogyakarta: Student Library, 2008.

[9] H. Susanto, The Dynamics of Poverty Reduction. Jakarta: Khanata-Pustaka LP3ES, 2006.

[10] Alfani Daud, The Tramp View of Social Sciences. jakarta: LP3ES, 1984.

[11] Y. Apriati, "Case Study of Homeless Beggars in Tanah Bumbu Regency, South Kalimantan," Wiramartas, vol. 1, pp. 95-106, 2014.

[12] PR Mukti, "Beggars' Strategy in Community Life in the City of Surabaya," Community, vol. 3, no. 1, pp. 1-15, 2014, [Online]. Available: http://www.eskom.co.za/CustomerCare/TariffsAnd Charges/Documents/RSA Distribution Tariff Code Vers 6.pdf\% 0Ahttp: //www.nersa.org.za/.

[13] A. Rohman, Module for Social Services and Rehabilitation of Homeless and Beggars at the Home. Yogyakarta, 2011.

[14] U. Supraptiningsih, "Characteristics of Female Beggars in Tlanakan District, Pamekasan Regency," NUANSA J. Researcher. Science Sos. and Islamic Religion, vol. 13, no. 2, p. 357, 2016, doi: 10.19105 / nuance.v13i2.1104. 